\title{
Controllable fabrication of ordered Pt nanorod array as catalytic electrode for passive direct methanol fuel cells
}

\author{
Yanlin Wang a,b, Qingqing Cheng a,b, Ting Yuan ${ }^{\mathrm{b}}$, Yi Zhou ${ }^{\mathrm{b}}$, Haifeng Zhang b , Zhiqing Zou ${ }^{\mathrm{b}}$, \\ Jianhui Fang a,\#, Hui Yang b,* \\ a Department of Chemistry, College of Science, Shanghai University, Shanghai 200444, China \\ ${ }^{\mathrm{b}}$ Shanghai Advanced Research Institute, Chinese Academy of Sciences, Shanghai 201210, China
}

\section{A R T I C L E I N F O}

Article history:

Received 28 January 2016

Accepted 3 March 2016

Published 5 July 2016

Keywords:

Catalytic electrode

Ordered nanorod

Catalyst utilization

Direct methanol fuel cell

\begin{abstract}
A B S T R A C T
The nanostructure of the catalytic electrode has a great effect on the performance of direct methanol fuel cells (DMFCs), including catalyst utilization, precious metal loading, water balance, and oxygen mass transfer. In this work, ordered arrays of platinum nanorods with different diameters were directly grown onto microporous layers by electrodeposition via a sacrificial template, and were used as the catalytic cathode for passive DMFCs. The use of these ordered electrodes led to a dramatic decrease in cathode polarization behavior. The maximum power density of passive DMFCs fabricated with catalytic electrodes of 200 and $100 \mathrm{~nm}$ Pt nanorod arrays were 17.3 and 12.0 $\mathrm{mW} / \mathrm{cm}^{2}$, respectively. The obtained improvement in performance was ascribed to the fact that the ordered nanostructured electrode not only increased the electrochemically active surface area and the catalyst utilization, but also enhanced oxygen mass transfer and water balance in the system.
\end{abstract}

(C) 2016, Dalian Institute of Chemical Physics, Chinese Academy of Sciences.

Published by Elsevier B.V. All rights reserved.

\section{Introduction}

Passive direct methanol fuel cells (DMFCs) have attracted broad interest as potential power sources for portable applications owing to their high energy density and non-polluting nature, as well as their availability and ease of storage of methanol [1-4]. Critical technical challenges for their large-scale application include improving cell performance, reducing costs, and reliable extension of their life-time. Because the catalytic electrodes represent the majority of the cost and performance of DMFCs [5,6], their electrocatalytic activity and loading of precious metals directly affect the performance and cost of DMFCs. Therefore, the development of catalytic electrodes with high performance and low cost is highly desirable. Particularly for passive DMFCs, the serious "water flooding" problem and limited oxygen mass transfer within the catalytic electrode need to be addressed [6-9].

With the recent development of nanotechnology, ordered nanostructures have been increasingly applied to the construction of catalytic electrodes for DMFCs, which can lead to enhanced cell performance. Debe [6] has reviewed the present status, challenges, and opportunities in the development of hydrogen-oxygen fuel cells as power supplies for automobiles, and summed up the relationship between catalytic electrode performance and various experimental factors, including catalyst type and support. He pointed out that one of the major research trends was to develop ordered nanostructured catalytic electrodes with low loadings of precious metals and high

\footnotetext{
* Corresponding author. Tel/Fax: +86-21-20321112; E-mail: yangh@sari.ac.cn

\# Corresponding author. Tel/Fax: +86-21-66132663; E-mail: jhfang@shu.edu.cn

This work was supported by the National Basic Research Program of China (973 Program, 2012CB932800) and the National Natural Science Foundation of China $(21533005,21276158,21303243,51506213)$.

DOI: 10.1016/S1872-2067(15)61077-4 | http://www.sciencedirect.com/science/journal/18722067 | Chin. J. Catal., Vol. 37, No. 7, July 2016
} 
performance in the final fuel cells. Recently, Sun et al. [10] reported the construction of highly ordered nanoarrays of polypyrrole on the surface of Pd-modified Nafion membrane via electrochemical polymerization, which yielded a significantly enhanced maximum DMFC power density. Following this idea, Yang et al. [11] reported the preparation of a Nafion membrane with ordered anodes via nano-imprint technology. The nano-imprint technology was capable of increasing the utilization of the anode catalyst, improving the DMFC performance by nearly $60 \%$. However, current literature primarily focuses on investigations into nano-ordered microporous layers on membrane electrode assemblies [12-15], nano-ordered membranes [16,17], Pt nanoparticle deposition on different supports to improve anode performance [18-20], and the reduction of precious metal loading at the anode [21-23]. Few reports have focused on the construction of ordered nanostructured catalytic electrodes for the cathode.

In this work, catalytic electrodes formed from arrays of $\mathrm{Pt}$ nanorods with different diameters and ordered arrangements were prepared on a cathodic microporous layer by electrodeposition via a sacrificial template approach [24-30], and were used as catalytic cathodes for passive DMFCs. The use of such ordered electrodes as the catalytic cathode was found to lead to a dramatic decrease in the cathode polarization behavior, thus enhancing the performance of the DMFCs.

\section{Experimental}

\subsection{Reagents and instruments}

The raw materials and reagents used in this work included carbon powder XC-72R (Cabot Corporation, USA), carbon nanotubes (CNT, Shenzhen Nanotech, Inc., China), platinum-ruthenium alloy (atomic ratio of 1:1, Johnson Matthey), platinum black (Johnson Matthey), carbon paper (E-TEK C60), PTFE emulsion, Nafion solution, Nafion membrane (Dupont Co. USA), anodic aluminum oxide template (AAO, Whatman), 1-methyl-2-pyrrolidinone (NMP), polyvinylidene fluoride (PVDF), methanol, isopropanol, perchloric acid, lead acetate, and sodium hydroxide (Sinopharm Chemical Reagent Co., Ltd., China).

An X-ray diffractomer (XRD; Bruker D8 ADVANCE) was used to analyze the crystal morphology of the catalysts. Scanning electron microscopy (SEM; Hitachi S-4800) and transmission electron microscopy (TEM; JEOL JEM-2100F) instruments were used to characterize the morphology of the catalytic cathode. An FCT fuel cell integrated testing system (Arbin, USA) was used to characterize the discharge performance of single cells. Electrochemical tests and impedance spectral analyses were performed using an impedance analyzer and an SI1287 potentiostat equipped with a 1255B frequency response analyzer (Solartron, UK).

\subsection{Preparation of Pt nanorod array catalytic electrode}

Pt nanorod arrays were prepared using a template-based electrochemical deposition. In a typical synthesis, a slurry con- sisting of CNTs and $20 \mathrm{wt} \%$ PTFE was hand painted onto C60 carbon paper to prepare a microporous layer containing a carbon powder loading of $2.0 \mathrm{mg} / \mathrm{cm}^{2}$ and a PTFE loading of 0.5 $\mathrm{mg} / \mathrm{cm}^{2}$. The microporous layer was then bonded to the AAO template using a 5.3\% PVDF suspension with NMP as solvent, and used as the working electrode for electrochemical deposition of the Pt nanorod. Pt wire and a saturated calomel electrode were used as the counter electrode and reference electrode, respectively. The electrolyte contained about 6-10 mmol/L chloroplatinic acid, $0.12-0.20 \mathrm{mmol} / \mathrm{L}$ lead acetate, and $0.1 \mathrm{~mol} / \mathrm{L}$ perchloric acid solution. The cyclic voltammetric deposition was carried out with a potential scanning range of $-0.5-0.0 \mathrm{~V}$ at a scanning speed of $0.1 \mathrm{~V} / \mathrm{s}$ and a scanning time of 8000-15000 s, corresponding to 1600-3000 cycles. After deposition, the AAO template was removed by immersing the specimen in a $2 \mathrm{~mol} / \mathrm{L} \mathrm{NaOH}$ etching solution for $1 \mathrm{~h}$. The PVDF binder was removed by washing with NMP, after which the array was washed with deionized water and dried. Finally, the surface of the Pt nanorod array was spray-coated with Nafion solution to a resin loading of about $0.25 \mathrm{mg} / \mathrm{cm}^{2}$ (about 20 wt $\%$ of the catalytic layer), and then heat-treated at $105^{\circ} \mathrm{C}$ for $3 \mathrm{~h}$.

\subsection{Preparation of membrane electrode assembly (MEA)}

The membrane electrode assembly (MEA) was prepared via a conventional gas diffusion layer (GDL) method. In a typical procedure, the microporous layer was prepared by coating C60 carbon paper with a slurry containing carbon powder and 20 wt $\%$ PTFE (mass ratio of carbon:PTFE $=4: 1$ ), in which the carbon powder consisted of either XC-72R or CNTs and yielded a loading of $2.0 \mathrm{mg} / \mathrm{cm}^{2}$. Using the method described above, $\mathrm{Pt}$ nanorod arrays were prepared on the CNTs to a Pt loading of $1.0 \mathrm{mg} / \mathrm{cm}^{2}$. The surface was then sprayed with Nafion solution until the Nafion loading reached $0.25 \mathrm{mg} / \mathrm{cm}^{2}$. For comparison, a Pt black catalyst/Nafion (mass ratio $=4: 1$ ) slurry was spray-coated on XC-72R with a Pt loading of $1.0 \mathrm{mg} / \mathrm{cm}^{2}$. The anode microporous layer and catalytic anode were prepared using a similar method. The anode microporous layer consisted of XC-72R and PTFE at loadings of 1.0 and $0.25 \mathrm{mg} / \mathrm{cm}^{2}$, respectively. The anodic catalytic layer consisted of $4.0 \mathrm{mg} / \mathrm{cm}^{2}$ of Pt-Ru catalyst and $15 \mathrm{wt} \%$ Nafion resin. Finally, both catalytic electrodes were bonded on each side of a Nafion 115 membrane and hot-pressed at $130{ }^{\circ} \mathrm{C}$ and $2 \mathrm{MPa}$ for $3 \mathrm{~min}$ to form a multi-layered MEA with an effective area of $1 \times 1 \mathrm{~cm}^{2}$.

\subsection{Structural characterization and performance evaluation of the catalytic electrode}

The steady-state polarization curve of the catalytic cathodes was measured using an SI1287 potentiostat. During each measurement, humidified oxygen was inlet into the cathode side of the MEA, which acted as the working electrode, while humidified hydrogen was inlet into the anode side, which acted as the counter electrode and reference electrode, namely, the dynamic hydrogen electrode (DHE). Steady-state voltages were recorded for a series of scanning currents to obtain the polari- 
zation curves of the cathode.

The steady-state polarization curve of each MEA was evaluated using a fuel cell testing system in which the MEA was fixed between anode and cathode metal flow field plates. The cathode was set to the air-breathing mode and the anode to the passive fuel diffusion mode. The typical fuel was a methanol solution $(4.0 \mathrm{~mol} / \mathrm{L})$ and the cell temperature was kept at $25 \pm 1$ ${ }^{\circ} \mathrm{C}$. The terminal voltages and variation in current were measured using the FCT fuel cell integrated testing system. By measuring the equilibrium voltages of the fuel cell under various current densities, the steady-state polarization curve and power density curve of the cell were obtained.

The electrochemically active surface area of the catalytic cathode was measured using cyclic voltammetry (CV). Humidified nitrogen was inlet into the MEA cathode as the working electrode while humidified hydrogen was inlet to the anode as the counter and reference electrode. The voltage was scanned between $0.00-0.75 \mathrm{~V} / \mathrm{DHE}$ at a scanning rate of $20 \mathrm{mV} / \mathrm{s}$ until the curve reached a steady state. The resultant curves were recorded and used to calculate the electrochemically active surface area of the electrode based on its hydrogen desorption area.

Electrochemical impedance spectroscopy (EIS) of the fuel cell was conducted using the DMFC testing system, in which the cathode was used as the working electrode, the anode as the counter and reference electrode, and $4 \mathrm{~mL}$ methanol solution ( $4.0 \mathrm{~mol} / \mathrm{L}$ ) was used as the anode fuel. The working voltage of the cell and the sine wave amplitude of the AC signal were 0.35 $\mathrm{V}$ and $10 \mathrm{mV}$, respectively. Automatic scanning was implemented from the high to the low frequency region, with a scanning frequency range of $100 \mathrm{kHz}$ to $0.01 \mathrm{~Hz}$ at a temperature of $25 \pm 1^{\circ} \mathrm{C}$.

\section{Results and discussion}

\subsection{Physical characterization}

Fig. 1 shows the XRD patterns of two catalytic cathodes. Both electrodes displayed the characteristic diffraction peaks of Pt (111), (200), (220), (311), and (222) after the electrodeposition. The positions of the peaks were consistent with the char-

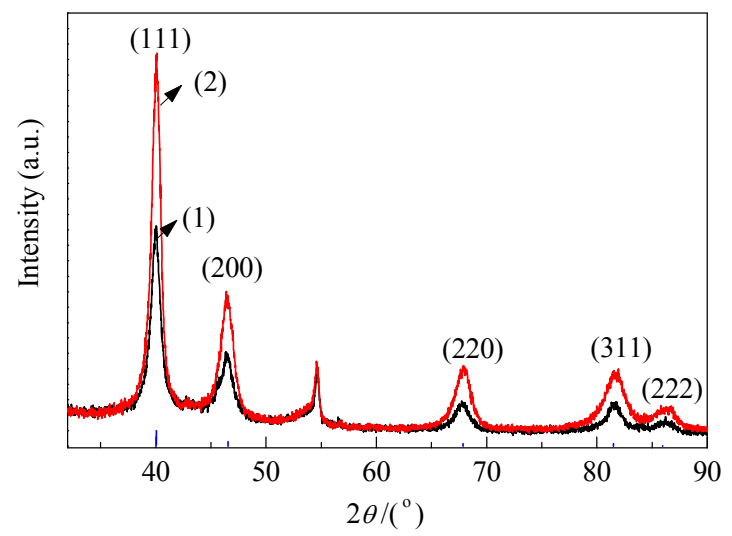

Fig. 1. XRD patterns of commercial Pt black catalytic electrode (1) and Pt nanorod array catalytic electrode with a diameter of $100 \mathrm{~nm}(2)$. acteristic peaks of the commercial Pt black nanoparticle catalytic electrodes and with JCSPD Card 01-1994, confirming that Pt nanomaterial was successfully prepared by the template-based electrodeposition approach. The other peaks in Fig. 1 can be attributed to carbon from the CNTs in the microporous layer. The XRD pattern of the electrode composed of Pt nanorods with a diameter of $200 \mathrm{~nm}$ was quite similar to that of the electrode with $100 \mathrm{~nm}$-diameter Pt nanorods.

SEM images of the catalytic layers prepared with commercial Pt black and the Pt nanorod array are shown in Fig. 2. It is clear that Pt nanorod arrays were successfully prepared via the electrochemical deposition. Compared with the commercial Pt black catalytic layer, the nano-ordered array demonstrated a relatively loosely-packed structure because the nanorods did not form the compact aggregates seen for the commercial Pt black nanoparticles, which was expected to provide an efficient channel for mass transfer. The single Pt nanorod possessed a diameter of about $100-200 \mathrm{~nm}$, consistent with the pore size of the template (Fig. 2(b)). Nanoarrays consisting of an arrangement of one-dimensional structures have been shown to exhibit anisotropic and unique surface properties [24], as well as adequate electrocatalytic performance and durability [30]. Additionally, the nanorod arrays appeared to be more stable and less prone to aggregate formation than the commercial $\mathrm{Pt}$ nanoparticles.

Fig. 3 shows typical TEM images of individual Pt nanorod. The length of the Pt nanorods was in the range of $1-3 \mu \mathrm{m}$ and their diameter was either 100 or $200 \mathrm{~nm}$, determined by the pore diameter of the AAO template. The surface of the single Pt nanorod exhibited whisker-like nanostructures of about $20 \mathrm{~nm}$ in diameter. This unique structure is likely to increase the electrochemically active surface area of the catalytic cathode [7].

\subsection{Characterization of the electrochemical performance}

The electrochemical polarization processes of the different DMFC cathodes for the oxygen reduction were comparatively analyzed. Fig. 4 shows that, for an identical Pt loading of 1.0 $\mathrm{mg} / \mathrm{cm}^{2}$, smaller cathode polarization yielded enhanced elec-

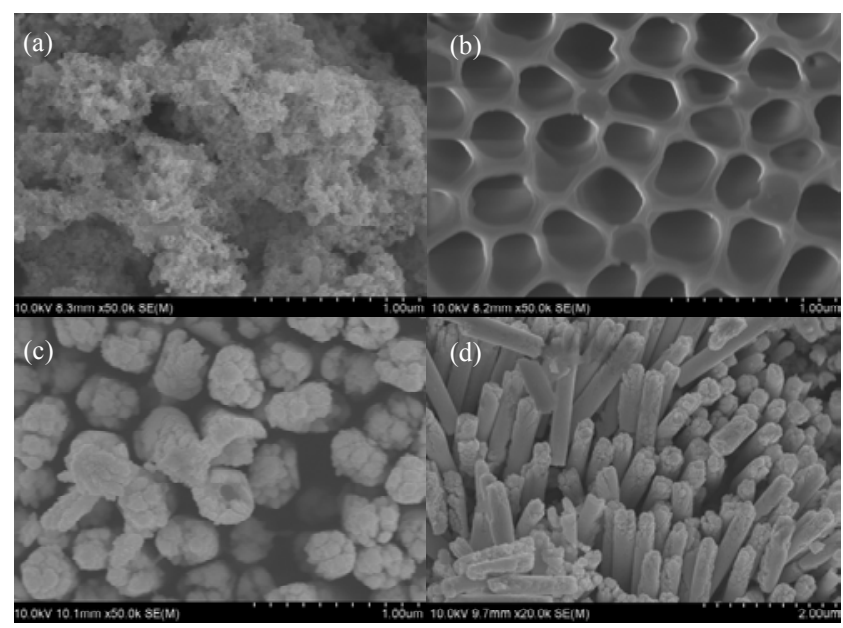

Fig. 2. SEM images of commercial Pt black catalytic layer (a), $200 \mathrm{~nm}$ AAO template (b), and Pt nanorod array catalytic layers (c, d). 


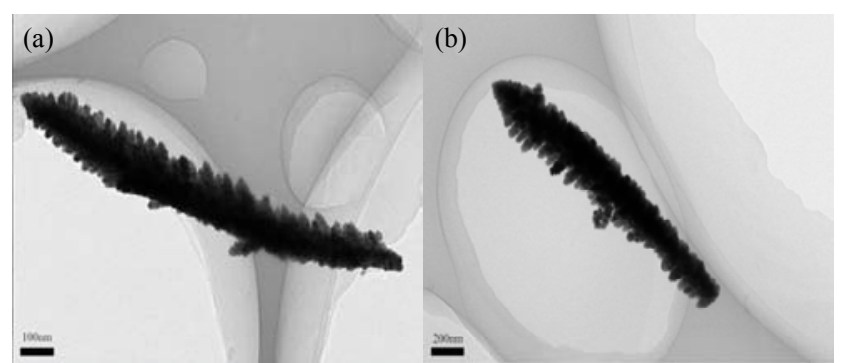

Fig. 3. TEM images of Pt nanorods with diameters of 100 (a) and 200 $\mathrm{nm}$ (b).

trocatalytic activity. The cathode potentials of the $200 \mathrm{~nm} \mathrm{Pt}$ nanorod array electrode were higher than those of the $100 \mathrm{~nm}$ Pt nanorod array electrode, which in turn were higher than those of the commercial Pt black catalytic electrode. This suggests that the catalytic layer of the $200 \mathrm{~nm}$ Pt nanorod array cathode operated with a smaller polarization and thus higher electrocatalytic activity. This higher catalytic activity despite the larger average particle size of the Pt nanorods (from XRD) than that of the commercial Pt black catalytic layer was attributed to its unique ordered nanostructure. The uniformly distributed, one-dimensional, ordered, sub-micron sized channels among the Pt nanorods likely improved the mass transfer of both oxygen and water. Furthermore, the distinct whisker-like nanostructure of the nanorods provided a high specific surface area and would prevent aggregation during electrochemical measurements.

Fig. 5 shows the DMFC steady-state polarization curves of the MEAs prepared with different catalytic layers. At low current density $\left(\leq 30 \mathrm{~mA} / \mathrm{cm}^{2}\right)$, the MEA based on the $200 \mathrm{~nm} \mathrm{Pt}$ nanorod array catalytic electrode exhibited the highest cell voltage, followed by the MEA with the $100 \mathrm{~nm}$ Pt nanorod array catalytic electrode, while that based on the commercial Pt black catalytic electrode had the lowest cell voltage. In this region, the main polarization type was electrochemical activation polarization, which is dependent on electrocatalytic activity and

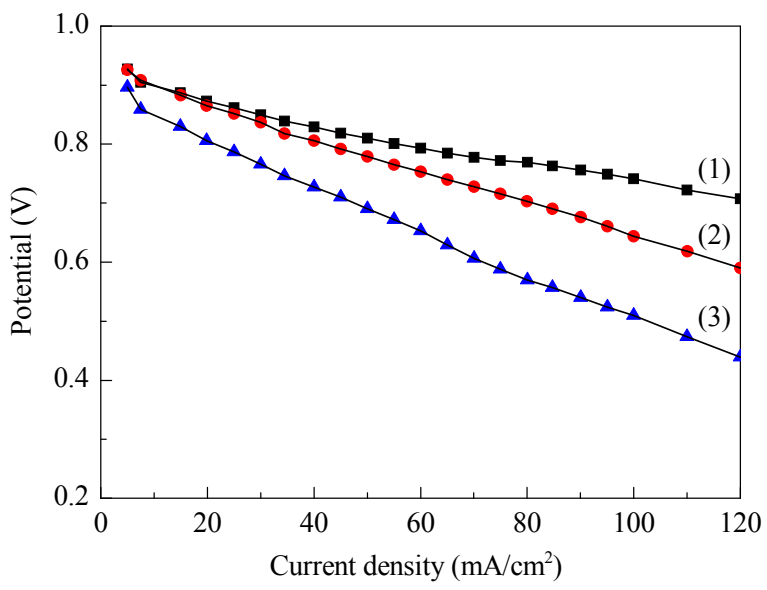

Fig. 4. Cathode polarization curves of MEAs with the Pt loading of 1.0 $\mathrm{mg} / \mathrm{cm}^{2}$ at $25 \pm 1^{\circ} \mathrm{C}$. (1) $200 \mathrm{~nm}$ Pt nanorod array catalytic electrode; (2) $100 \mathrm{~nm}$ Pt nanorod array catalytic electrode; (3) Commercial Pt black catalytic electrode.

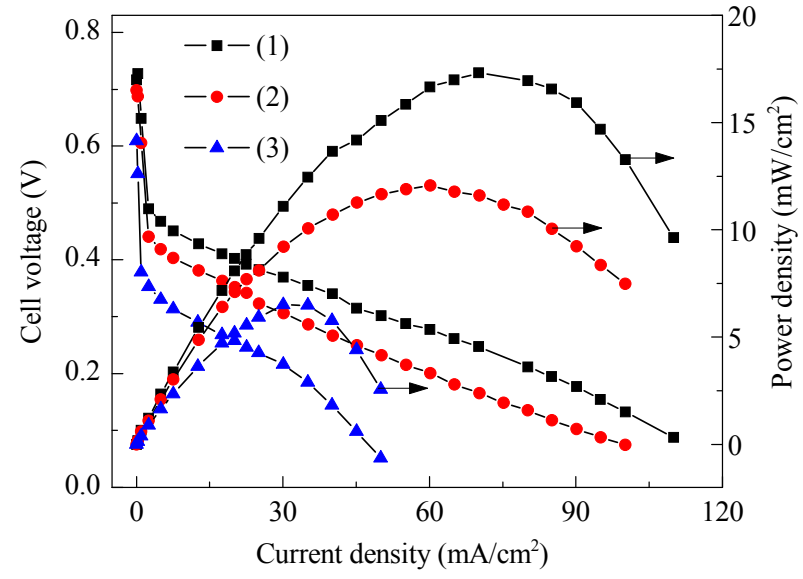

Fig. 5. Polarization curves of MEAs with a Pt loading of $1.0 \mathrm{mg} / \mathrm{cm}^{2} \mathrm{fed}$ with $4.0 \mathrm{~mol} / \mathrm{L}$ methanol solution at $25 \pm 1{ }^{\circ} \mathrm{C}$. (1) $200 \mathrm{~nm}$ Pt nanorod array catalytic electrode; (2) $100 \mathrm{~nm}$ Pt nanorod array catalytic electrode; (3) Commercial Pt black catalytic electrode.

catalyst loading. Thus, the MEA with the $200 \mathrm{~nm}$ Pt nanorod array catalytic electrode exhibited a higher performance and higher electrocatalytic activity than those of the MEA with the commercial Pt black catalytic electrode, consistent with the results of the cathode polarization curves. Throughout the ohmic polarization region (with medium current density) and the mass transfer polarization region (with larger current density), the cell voltage of the DMFC with commercial Pt black catalytic electrode declined rapidly, mainly owing to the low loading of the Pt black catalyst and the tendency of the Pt black nanoparticles to aggregate. However, the cell voltage of the DMFCs with 200 and $100 \mathrm{~nm}$ Pt nanorod array catalytic electrodes demonstrated a more gradual decrease, while the limited diffusion current densities of the cells were significantly improved. The maximum power densities of the passive DMFCs fabricated with 200 and $100 \mathrm{~nm}$ Pt nanorod array cathode catalytic layers were 17.3 and $12.0 \mathrm{~mW} / \mathrm{cm}^{2}$, respectively, indicating that, for the same Pt loading, the MEA performance of the Pt nanorod array was significantly improved over that of the commercial Pt black catalytic layer.

To further explore the reasons for the improved performance of the Pt nanorod array based DMFCs, the electrochemically active specific surfaces of the different MEAs were investigated. Fig. 6 shows the cyclic voltammograms of the cathodes. The electrochemically active area was calculated by integrating the hydrogen desorption area. The electrochemically active areas of the MEA cathodes consisting of $200 \mathrm{~nm}$ Pt nanorod array, $100 \mathrm{~nm}$ Pt nanorod array, and commercial Pt black were 48.6, 36.2, and $23.9 \mathrm{~m}^{2} / \mathrm{g}(\mathrm{Pt})$, respectively. Comparisons carried out with identical Pt loadings suggested that the electrochemically active surface areas of the 200 and $100 \mathrm{~nm}$ Pt nanorod array catalytic electrodes were approximately 2 and 1.5 times that of the commercial Pt black catalytic electrode, respectively. Combined with the results from the steady-state polarization curves discussed above, the enhanced cell performance obtained with the Pt nanorod arrays can be attributed to the high electrochemically active area of the nanorod array 


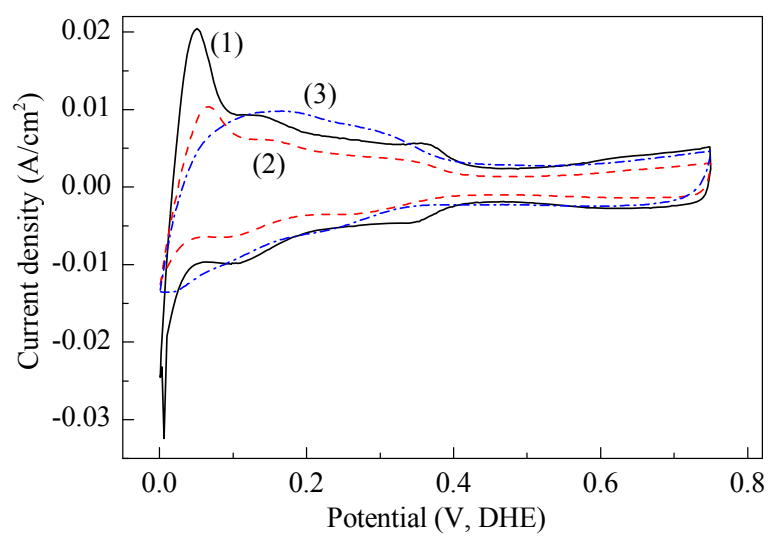

Fig. 6. Cyclic voltammograms of cathodes with a Pt loading of 1.0 $\mathrm{mg} / \mathrm{cm}^{2}$ at a scan rate of $20 \mathrm{mV} / \mathrm{s}$. (1) $200 \mathrm{~nm}$ Pt nanorod array catalytic electrode; (2) $100 \mathrm{~nm}$ Pt nanorod array catalytic electrode; (3) Commercial Pt black catalytic electrode.

structure. In the case of the $100 \mathrm{~nm}$ Pt nanorod array, the cathode was probably easily water-flooded owing to the narrow distance between individual nanorods, thus leading to insufficient oxygen transfer and poorer performance of the final DMFC compared with that based on the $200 \mathrm{~nm}$ Pt nanorod array.

The effect of the Pt nanorod array structure on DMFC performance was further analyzed using electrochemical impedance spectroscopy as shown in Fig. 7. The equivalent circuit is displayed in Fig. 7 (b) and the fitted parameters are listed in Table 1. The physical meanings of $R_{2}$ and $L_{1}$ are the resistance and inductance in the system, respectively, probably because of the porous electrodes or the equipment conducting cables. $R_{1}$ denotes the ohmic resistance of the fuel cell. $R_{3}$ and $R_{5}$ are attributed to the charge-transfer resistances of the cathodic and anodic reactions, respectively. The two CPEs employed in the
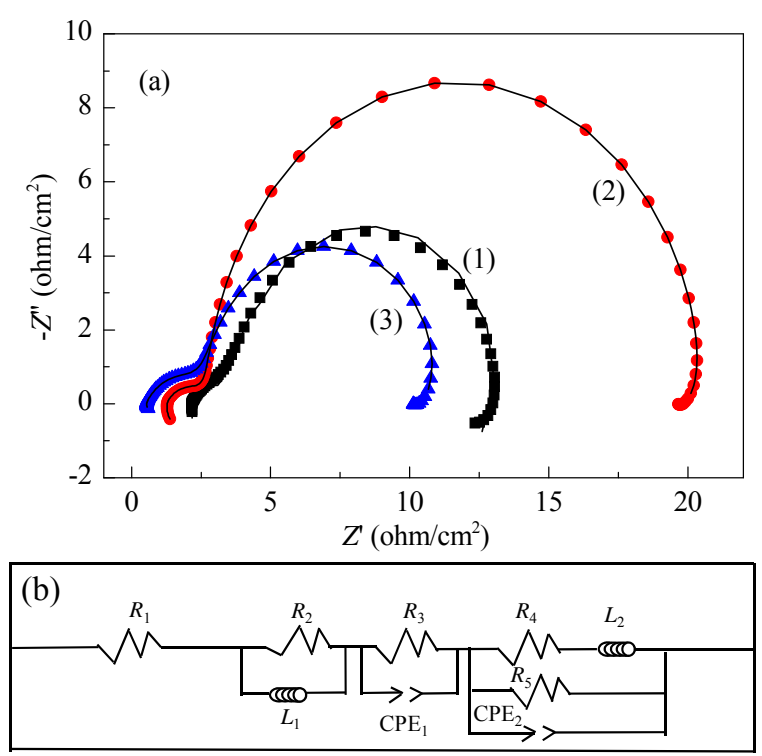

Fig. 7. (a) Impedance spectra of MEAs with (1) $200 \mathrm{~nm}$ Pt nanorod array catalytic electrode, (2) $100 \mathrm{~nm}$ Pt nanorod array catalytic electrode, and (3) commercial Pt black catalytic electrode; (b) Equivalent circuit model.
Table 1

CPE-based equivalent circuit model fitted parameters of the MEAs operated at $0.35 \mathrm{~V}$ and $25 \pm 1^{\circ} \mathrm{C}$.

\begin{tabular}{lccc}
\hline Parameter & $\begin{array}{c}200 \mathrm{~nm} \text { Pt } \\
\text { nanorod array } \\
\text { catalytic } \\
\text { electrode }\end{array}$ & $\begin{array}{c}100 \mathrm{~nm} \text { Pt } \\
\text { nanorod array } \\
\text { catalytic } \\
\text { electrode }\end{array}$ & $\begin{array}{c}\text { Commercial } \\
\text { Pt black } \\
\text { catalytic } \\
\text { electrode }\end{array}$ \\
\hline$R_{1}\left(\mathrm{ohm} / \mathrm{cm}^{2}\right)$ & 2.135 & 1.23 & 0.512 \\
$R_{2}\left(\mathrm{ohm} / \mathrm{cm}^{2}\right)$ & 1.50 & 1.49 & 1.51 \\
$L_{1}\left(10^{-7} \mathrm{H} / \mathrm{cm}^{2}\right)$ & 6.03 & 6.02 & 6.01 \\
$R_{3}\left(\mathrm{ohm} / \mathrm{cm}^{2}\right)$ & 9.12 & 18.1 & 10.6 \\
$\mathrm{CPE} \mathrm{E}_{1}-\mathrm{T}\left(\mathrm{F} / \mathrm{cm}^{2}\right)$ & 0.018 & 0.025 & 0.12 \\
$\mathrm{CPE} 1-\mathrm{P}$ & 0.99 & 0.98 & 0.86 \\
$R_{4}\left(\mathrm{ohm} / \mathrm{cm}^{2}\right)$ & 0.65 & 0.61 & 0.65 \\
$L_{2}\left(\mathrm{H} / \mathrm{cm}^{2}\right)$ & 20.1 & 20.4 & 20.5 \\
$R_{5}\left(\mathrm{ohm} / \mathrm{cm}^{2}\right)$ & 1.9 & 1.56 & 2.0 \\
$\mathrm{CPE} 2-\mathrm{T}\left(\mathrm{F} / \mathrm{cm}^{2}\right)$ & 0.02 & 0.01 & 0.025 \\
$\mathrm{CPE}-\mathrm{P}$ & 0.61 & 0.61 & 0.65 \\
\hline
\end{tabular}

model describe the capacitive nature of the real cathode and anode with roughness of the catalytic layer and non-uniform catalyst distribution. $R_{4}$ and $L_{2}$ account for the phase delay with respect to the voltage perturbation because of the slowness of CO desorption [31]. The experimental results indicated that the ohmic resistance $\left(R_{1}\right)$ of the MEAs with Pt nanorod array catalytic electrode was higher than that with commercial the $\mathrm{Pt}$ black catalyst electrode, possibly because of the increased resistance of the PVDF residue used for binding the AAO template and GDL. The charge-transfer resistance $\left(R_{3}\right)$ of the MEA with the $200 \mathrm{~nm}$ Pt nanorod array was close to that of the MEA with the commercial Pt black catalytic electrode, but less than that of the MEA with the $100 \mathrm{~nm}$ Pt nanorod array catalytic electrode. This could be because of the fact that the cathode with $200 \mathrm{~nm}$ Pt nanorod array had a higher surface area, and that the sparser spatial arrangement within the ordered structure will favor the mass transfer of oxygen, thus explaining the improved performance of the DMFC. For the cathode with $100 \mathrm{~nm}$ Pt nanorod array, the closer nanorod arrangement and lower surface area led to an increased the charge transfer resistance. $R_{2}$ and $L_{1}$ in Table 1 are the resistance and inductance of the conductor, respectively; while $R_{4}, L_{2}, R_{5}, \mathrm{CPE}_{2}-\mathrm{T}$, and $\mathrm{CPE}_{2}-\mathrm{P}$ are the corresponding relevant parameters for the anodic catalytic layer.

To investigate the durability of a passive DMFC with Pt nanorod array catalytic electrode $\left(1.0 \mathrm{mg} / \mathrm{cm}^{2}\right)$, the MEA was continuously discharged at a given current density of 40 $\mathrm{mA} / \mathrm{cm}^{2}$. As seen in Fig. 8, a steady cell performance was observed for a period of more than $100 \mathrm{~h}$, demonstrating a good stability of the Pt nanorod array based MEA.

\section{Conclusions}

Pt nanorod arrays with different diameters were constructed on the surface of microporous cathodic DMFC layers using an ordered aluminum oxide template and electrodeposition method. The array was then used as the catalytic cathode. The surface morphology, size, and crystallinity of the Pt nanomaterials were investigated, and their electrochemically active 


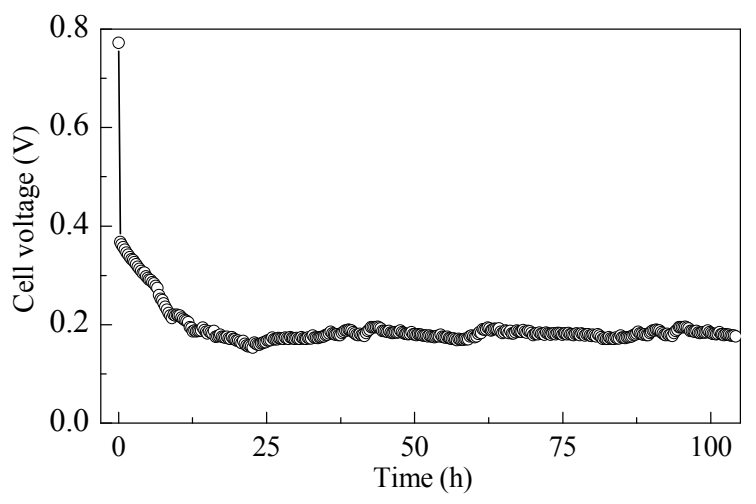

Fig. 8. Discharging curve of passive DMFC with $200 \mathrm{~nm}$ Pt nanorod array catalytic electrode $\left(1.0 \mathrm{mg} / \mathrm{cm}^{2}\right)$ at a constant current of 40 $\mathrm{mA} / \mathrm{cm}^{2}$.

surface area was analyzed. The relationship between the ordered nanoarray structure of the catalytic electrode and the resulting cell performance was evaluated. The DMFC assembled with the Pt nanorod array catalytic electrode with a nanorods diameter of $200 \mathrm{~nm}$ and loading of $1.0 \mathrm{mg} / \mathrm{cm}^{2}$ possessed a maximum power density of $17.3 \mathrm{~mW} / \mathrm{cm}^{2}$, indicative of a greatly enhanced performance. Our proposed synthetic route for catalytic electrodes based on ordered nanostructures provides a new technological approach for the future development of high-performance and low-cost DMFCs.

\section{References}

[1] X. L. Li, A. Faghri, J. Power Sources, 2013, 226, 223-240.

[2] S. K. Kamarudin, F. Achmad, W. R. W. Daud, Int. J. Hydrogen Energy, 2009, 34, 6902-6916.

[3] S. Wasmus, A. Kuver, J. Electroanal. Chem., 1999, 461, 14-31.

[4] T. S. Zhao, R. Chen, W. W. Yang, C. Xu, J. Power Sources, 2009, 191, 185-202.

[5] Y. Qiao, C. M. Li, J. Mater. Chem., 2011, 21, 4027-4036.
[6] M. K. Debe, Nature, 2012, 486, 43-51.

[7] G. Q. Lu, F. Q. Liu, C. Y. Wang, Electrochem. Solid State Lett., 2005, 8, A1-A4.

[8] L. J. Pu, H. F. Zhang, T. Yuan, Z. Q. Zou, L. L. Zou, X. M. Li, H. Yang, J. Power Sources, 2015, 276, 95-101.

[9] J. S. Chai, Y. Zhou, J. Fan, J. J. Jiang, T. Yuan, H. F. Zhang, Z. Q. Zou, H. D. Qian, H. Yang, Int. J. Hydrogen Energy, 2015, 40, 6647-6654.

[10] Z. X. Xia, S. L. Wang, Y. J. Li., L. H. Jiang, H. Sun., S. Zhu, D. S. Su, G. Q. Sun, J. Mater. Chem. A, 2013, 1, 491-494.

[11] L. J. Pu, J. J. Jiang, T. Yuan, J. S. Chai, H. F. Zhang, Z. Q. Zou, X. M. Li, H. Yang, Appl. Surf. Sci., 2015, 327, 205-212.

[12] H. J. Wu, T. Yuan, Q. H. Huang, H. F. Zhang, Z. Q. Zou, J. W. Zheng, H. Yang, Electrochim. Acta, 2014, 141, 1-5.

[13] V. Selvaraj, M. Alagar, Electrochem. Commun., 2007, 9, 1145-1153.

[14] Z. X. Xia, S. L. Wang, L. H. Jiang, H. Sun, G. Q. Sun, J. Power Sources, 2014, 256, 125-132.

[15] M. H. Yildirim, J. te Braake, H. C. Aran, D. F. Stamatialis, M. Wessling, J. Membr. Sci., 2010, 349, 231-236.

[16] Z. L. Zhou, R. N. Dominey, J. P. Rolland, B. W. Maynor, A. A. Pandya, J. M. Desemone, J. Am. Chem. Soc., 2006, 128, 12963-12972.

[17] Q. H. Huang, J. J. Jiang, J. S. Chai, T. Yuan, H. F. Zhang, Z. Q. Zou, X. G. Zhang, H. Yang, J. Power Sources, 2014, 262, 213-218.

[18] H. Y. Chou, C. K. Hsieh, M. C. Tsai, Y. H. Wei, T. K. Yeh, C. H. Tsai, Thin Solid Films, 2015, 584, 98-102.

[19] T. S. Miller, S. Sansuk, S. Pei E, S. C. S. Lai, J. V. Macpherson, P. R. Unwin, Catal. Today, 2015, 244, 136-145.

[20] S. Dominguez-Dominguez, J. Arias-Pardilla, A. Berenguer-Murcia, E. Morallon, A. Dazorla-Cazorla, J. Appl. Electrochem., 2008, 38, 259-268.

[21] T. Yuan, Z. Q. Zou, M. Chen, Z. L. Li, B. J. Xia, H. Yang, J. Power Sources, 2009, 192, 423-428.

[22] H. T. Kim, T. V. Reshentenko, H. J. Kweon, J. Eletrochem. Soc., 2007, 154, B1034-B1039.

[23] S. M. Choi, J. H. Kim, J. Y. Jung, E. Y. Yoon, W. B. Kim. Electrochim. Acta, 2008, 53, 5804-5811.

[24] X. Y. Zhang, D. H. Dong, D. Li, T. Williams, H. T. Wang, P. A. Webley, Eletrochem. Commun., 2009, 11, 190-193.

[25] F. F. Tao, M. Y. Guan, Y. Jiang, J. M. Zhu, Z. Xu, Z. L. Xue, Adv. Mater., 2006, 18, 2161-2164.

\section{Graphical Abstract}

Chin. J. Catal., 2016, 37: 1089-1095 doi: 10.1016/S1872-2067(15)61077-4

Controllable fabrication of ordered Pt nanorod array as catalytic electrode for passive direct methanol fuel cells

Yanlin Wang, Qingqing Cheng, Ting Yuan, Yi Zhou, Haifeng Zhang, Zhiqing Zou, Jianhui Fang*, Hui Yang*

Shanghai University; Shanghai Advanced Research Institute, Chinese Academy of Sciences
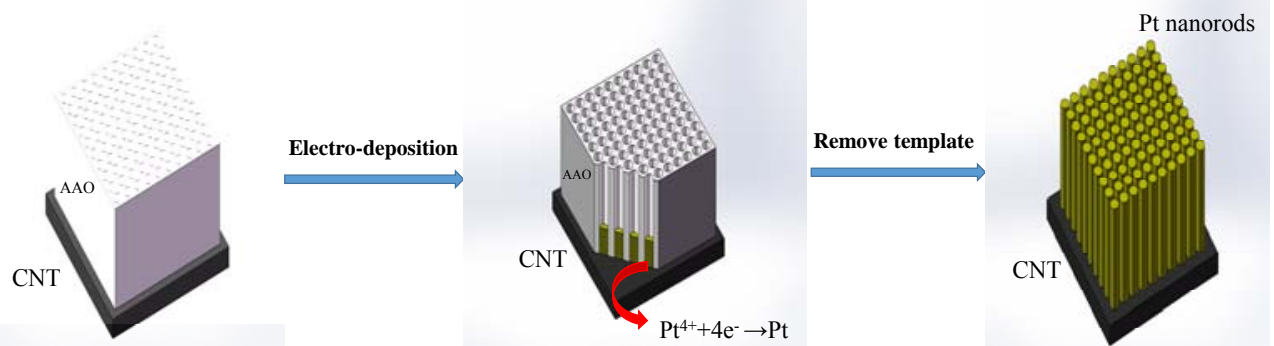

Ordered arrays of platinum nanorods with different diameters were directly grown onto microporous layers by electrodeposition with a sacrificial template, and used as the catalytic cathode for passive DMFCs. The application of such an ordered electrode as the catalytic electrode led to a dramatic decrease in cathode polarization behavior. 
[26] L. C. Liu, S. Park, Chem. Mater., 2011, 23, 1456-1460.

[27] C. H. Cui, H. H. Li, S. H. Yu, Chem. Commun., 2010, 46, 940-942.

[28] L. F. Liu, E. Pippel, R. Scholz, U. Gosele, Nano Lett., 2009, 9, 4352-4358.

[29] V. Roscher, M. Licklederer, J. Schumacher, G. R. Rios, B. Hoffmann,
S. Christiansen, J. Bachmann, Dalton Trans., 2014, 43, 4345-4350.

[30] D. D. Li, C. H. Jiang, J. H. Jiang, J. G. Lu, Chem. Mater., 2009, 21, 253-258.

[31] M. Chen, J. Chen, Y. Li, Q. H. Huang. H. F. Zhang, X. Z. Xue, Z. Q. Zou, H. Yang, Energy Fuels, 2012, 26, 1178-1184.

\section{铂纳米棒有序阵列催化电极在被动式直接甲醇燃料电池中的应用 \\ 汪艳林 ${ }^{\mathrm{a}, \mathrm{b}}$, 程庆庆 ${ }^{\mathrm{a}, \mathrm{b}}$, 袁 婷 ${ }^{\mathrm{b}}$, 周 毅 ${ }^{\mathrm{b}}$, 张海峰 ${ }^{\mathrm{b}}$, 邹志青 ${ }^{\mathrm{b}}$, 方建慧 ${ }^{\mathrm{a}, \text {, }}$, 杨 辉, ${ }^{\mathrm{b}}$, \\ ${ }^{a}$ 上海大学理学院化学系, 上海 200444 \\ b 中国科学院上海高等研究院, 上海 201210}

摘要: 直接甲醇燃料电池 (DMFC) 具有能量密度高、无需充电、液体燃料添加便捷及环境友好等优点, 是新一代便携式移 动电源研究热点. DMFC 规模应用的主要技术挑战是如何进一步提高电池性能、显著降低成本和可靠延长寿命. 催化电极 作为 DMFC 发电核心和成本的集中体现, 其电催化活性和贵金属用量直接影响 DMFC 的性能和成本, 开发高性能、低成本 的催化电极对推进 DMFC 实用化进程具有重要意义. 特别是在被动式 DMFC 中, 阴极催化电极不仅需要提高电催化活性 和大幅降低贵金属用量, 而且还面临内部严重的“水淹”和氧传质受限等问题. 近年来, 随着纳米技术发展, 有序纳米结构已 逐渐应用于 DMFC 催化电极的构筑中, 电池性能得到显著提高. 然而, 目前的研究主要集中在膜电极纳米有序微孔层、纳 米有序改性膜和纳米有序阳极催化电极及其阳极贵金属载量降低等方面, 关于阴极催化电极在有序纳米结构以及载量降 低等方面的研究相对较少.

本文采用模板法直接在微孔层上电沉积定向生长排列有序、直径可控的铂纳米棒阵列, 并作为阴极催化电极应用于被 动式 DMFC. X射线衍射和透射电镜结果表明, 该铂纳米棒结构稳定, 表面含有丰富的纳米晶须结构, 有利于催化电极比表 面积增加和电催化活性提高. 不同催化电极上氧还原的极化曲线表明电极性能依下列次序变化: 直径为 $200 \mathrm{~nm}$ 铂纳米棒 阵列电极 $>100 \mathrm{~nm}$ 铂纳米棒阵列电极 > 商业化铂黑催化电极. 电池性能表征表明, 长度为 1-3 $\mu \mathrm{m}$ 、直径分别为 200 和 100 $\mathrm{nm}$ 、载量为 $1.0 \mathrm{mg} / \mathrm{cm}^{2}$ 的铂纳米棒阵列作为阴极催化电极的 DMFC 最大功率密度分别为 17.3 和 $12.0 \mathrm{~mW} / \mathrm{cm}^{2}$. 通过催化 电极电化学活性面积和阻抗测试, 分析其性能提高的原因可归结于有序排列的铂纳米棒阵列结构提高了电化学活性面积、 增强了氧还原电催化活性并促进了阴极氧的传质.

关键词: 催化电极; 有序纳米棒; 催化剂利用; 直接甲醇燃料电池

收稿日期: 2016-01-28. 接受日期: 2016-03-03. 出版日期: 2016-07-05.

*通讯联系人. 电话/传真: (021)20321112; 电子信箱: yangh@sari.ac.cn

通讯联系人. 电话/传真: (021)66132663; 电子信箱: jhfang@shu.edu.cn

基金来源：国家重点基础研究发展计划 (973 计划, 2012CB932800); 国家自然科学基金 (21533005, 21276158, 21303243, 51506213).

本文的英文电子版由Elsevier出版社在ScienceDirect上出版(http://www.sciencedirect.com/science/journal/18722067). 